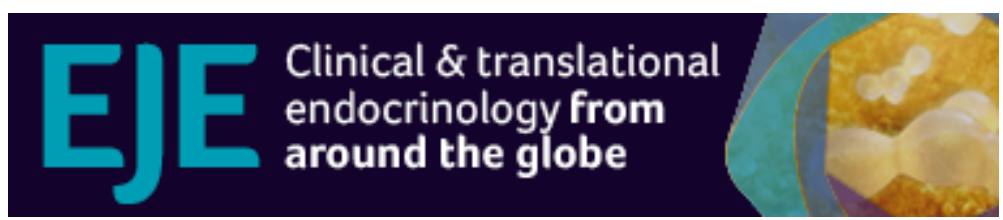

\title{
Increased Risk for Type 2 Diabetes in Relation to Adiposity in Middle-Aged Black South African Men compared to Women
}

\begin{tabular}{|c|c|}
\hline Journal: & European Journal of Endocrinology \\
\hline Manuscript ID & EJE-21-0527 \\
\hline mstype: & Clinical Study \\
\hline $\begin{array}{r}\text { Date Submitted by the } \\
\text { Author: }\end{array}$ & 17-May-2021 \\
\hline Complete List of Authors: & $\begin{array}{l}\text { Kufe, Clement; University of the Witwatersrand Faculty of Health } \\
\text { Sciences, Paediatrics; WITS University } \\
\text { Micklesfield, Lisa; South African Medical Research Council/University of } \\
\text { the Witwatersrand, Developmental Pathways for Health Research Unit } \\
\text { (DPHRU), Paediatrics } \\
\text { Masemola, Maphoko; 1South African Medical Research Council/University } \\
\text { of the Witwatersrand, Developmental Pathways for Health Research Unit } \\
\text { (DPHRU), Paediatrics } \\
\text { Chikowore, Tinashe; 1South African Medical Research Council/University } \\
\text { of the Witwatersrand, Developmental Pathways for Health Research Unit } \\
\text { (DPHRU), Paediatrics } \\
\text { Kengne, Andre; Non-Communicable Disease Research Unit, South } \\
\text { African Medical Research Council, Non-Communicable Disease Research } \\
\text { Unit } \\
\text { Karpe, Fredrik; University of Oxford, Oxford, UK, Oxford Centre for } \\
\text { Diabetes, Endocrinology and Metabolism; Oxford Medical Research } \\
\text { Centre, Oxford Radcliffe Hospitals Trust, OCDEM, Churchill Hospitsl, } \\
\text { Oxford, UK, National Institute for Health Research } \\
\text { Norris, Shane; South African Medical Research Council/University of the } \\
\text { Witwatersrand, Developmental Pathways for Health Research (DPHRU), } \\
\text { Paediatrics; School of Health and Human Development, University of } \\
\text { Southampton, UK, Global Health Research Institute } \\
\text { Crowther, Nigel; National Health Laboratory Service and University of } \\
\text { Witwatersrand, Department of Chemical Pathology } \\
\text { Olsson, Tommy; Umeå University, Department of Public Health and } \\
\text { Clinical Medicine, Medicine } \\
\text { Goedecke, Julia; South African Medical Research Council/University of } \\
\text { the Witwatersrand, Developmental Pathways for Health Research Unit } \\
\text { (DPHRU), Paediatrics; South African Medical Research Council, Non- } \\
\text { Communicable Diseases Research Unit }\end{array}$ \\
\hline Keywords: & Diabetes Mellitus, Insulin, Obesity \\
\hline
\end{tabular}


medRxiv preprint doi: https://doi.org/10.1101/2021.10.19.21265228; this version posted October 26, 2021. The copyright holder for this preprint

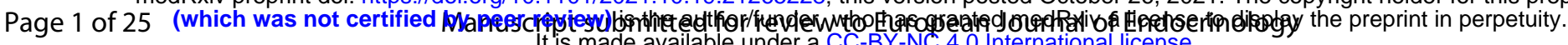
It is made available under a CC-BY-NC 4.0 International license.

eje@bioscientfica.com 
medRxiv preprint doi: https://doi.org/10.1101/2021.10.19.21265228; this version posted October 26, 2021. The copyright holder for this preprint (which was not certified by peer review) is the author/funder, who has granted medRxiv a license to display the preprint in perpetuity.

Increased Risk for Type 2 Diabetes in Relation to Adiposity in Middle-Aged Black

\section{South African Men compared to Women}

Clement N. Kufe ${ }^{1 \S}$, Lisa K. Micklesfield ${ }^{1}$, Maphoko Masemola ${ }^{1}$, Tinashe Chikowore ${ }^{1}$, Andre Pascal Kengne ${ }^{2}$, Fredrik Karpe ${ }^{3,4}$, Shane A. Norris ${ }^{1,5}$, Nigel J. Crowther ${ }^{6}$, Tommy Olsson 7 , Julia H. Goedecke ${ }^{1,2}$

\section{Authors affiliations:}

${ }^{1}$ South African Medical Research Council/University of the Witwatersrand, Developmental Pathways for Health Research Unit (DPHRU), Department of Paediatrics, Faculty of Health Sciences, University of the Witwatersrand, Johannesburg, South Africa

${ }^{2}$ Non-Communicable Diseases Research Unit, South African Medical Research Council, Cape Town, South Africa

${ }^{3}$ Oxford Centre for Diabetes, Endocrinology and Metabolism, University of Oxford, Oxford, UK

${ }^{4}$ National Institute for Health Research, Oxford Biomedical Research Centre, Oxford Radcliffe Hospitals Trust, OCDEM, Churchill Hospital, Oxford, UK

${ }^{5}$ Global Health Research Institute, School of Health and Human Development, University of Southampton, UK

${ }^{6}$ Department of Chemical Pathology, National Health Laboratory Service and School of Pathology, Faculty of Health Sciences, University of the Witwatersrand, Johannesburg, South Africa

${ }^{7}$ Department of Public Health and Clinical Medicine, Medicine, Umeå University, Umeå, Sweden 
medRxiv preprint doi: https://doi.org/10.1101/2021.10.19.21265228; this version posted October 26, 2021. The copyright holder for this preprint (which was not certified by peer review) is the author/funder, who has granted medRxiv a license to display the preprint in perpetuity. It is made available under a CC-BY-NC 4.0 International license.

\section{Running title: Increased Risk for T2D from Adiposity}

$\S$ Corresponding author

Clement N. Kufe

SAMRC/WITS Developmental Pathways for Health Research Unit,

Department of Paediatrics,

School of Clinical Medicine,

Faculty of Health Sciences,

University of the Witwatersrand, Johannesburg, South Africa

Phone: +27630926943

E-mail:kklekufe@gmail.com

\section{Email addresses:}

CNK: klekufe@gmail.com

LKM: 1isa.micklesfield@,wits.ac.za

MM: maphokomasemola@gmail.com

TC: tinashedoc@gmail.com

APK: andre.kengne@mrc.ac.za

FK: fredrik.karpe@ocdem.ox.ac.uk

SAN: shane.norris@wits.ac.za

NC: nigel.crowther@nhls.ac.za

TO: tommy.g.olsson@umu.se

JHG: julia.goedecke@mrc.ac.za

\section{Word count: 3498 (3500 maximum)}

\section{Number of tables and figures: 4}


medRxiv preprint doi: https://doi.org/10.1101/2021.10.19.21265228; this version posted October 26, 2021. The copyright holder for this preprint (which was not certified by peer review) is the author/funder, who has granted medRxiv a license to display the preprint in perpetuity.

\section{Abstract} It is made available under a CC-BY-NC 4.0 International license.

Aims: Despite a higher prevalence of overweight/obesity in black South African women compared to men, the prevalence of type 2 diabetes does not differ. We explored if this could be due to sex differences in insulin sensitivity, clearance and/or beta-cell function, and also sex-specific associations with total and regional adiposity.

Methods: This cross-sectional study included 804 black South African men $(n=388)$ and women $(\mathrm{n}=416)$. Dual-energy $\mathrm{x}$-ray absorptiometry was used to measure total and regional adiposity. Insulin sensitivity (Matsuda index), secretion (C-peptide index) and clearance (Cpeptide/insulin ratio) were estimated from an oral glucose tolerance test.

Results: After adjusting for sex differences in fat mass index, men were less insulin sensitive and had lower beta cell function than women $(\mathrm{p}<0.001)$, with the strength of the associations with measures of total and central adiposity being greater in men than women $(p<0.001$ for interactions). Further, the association between total adiposity and type 2 diabetes risk was also greater in men than women (relative risk ratio (95\% confidence interval): 2.05 (1.42-2.96), $\mathrm{p}<0.001$ vs. $1.38(1.03-1.85), \mathrm{p}=0.031)$.

Conclusion: With increasing adiposity, particularly increased centralisation of body fat linked to decreased insulin sensitivity and beta cell function, black African men are at greater risk for type 2 diabetes than their female counterparts.

Key words: Body fat distribution, insulin sensitivity, insulin secretion, beta-cell function, basal and postprandial insulin clearance, ethnicity. (Word count abstract: 207) 
medRxiv preprint doi: https://doi.org/10.1101/2021.10.19.21265228; this version posted October 26, 2021. The copyright holder for this preprint (which was not certified by peer review) is the author/funder, who has granted medRxiv a license to display the preprint in perpetuity.

\section{Introduction} It is made available under a CC-BY-NC 4.0 International license.

2 Type 2 diabetes (T2D) is a global health problem, with low-middle income countries

3 particularly affected. It is projected that sub-Saharan Africa will have the highest increase in 4 T2D compared to the rest of the world, and in 2019 South Africa (SA) had the highest estimated 5 number of people with diabetes (4.6 million) in the sub-Saharan region, and the highest age6 adjusted comparative prevalence of diabetes (12.7\%) in adults (1), which is higher than the 7 global average (2). Within SSA and SA, the prevalence of T2D does not differ by sex, despite 8 large sexual dimorphism in obesity rates (3). For example, in SA the prevalence of T2D in black SA men and women is similar (10.2\% vs. 13.8\%) (4), but the prevalence of overweight and obesity differs markedly (27.4\% vs. $67.4 \%)(5)$.

The reason for this discrepancy in the association between overweight/obesity and diabetes risk in men and women is not clear. Recent studies have started to explore the underlying pathophysiology of T2D in Africans (6-10), and shown that black African women present with a phenotype of low insulin sensitivity and hyperinsulinemia due to higher insulin secretion and lower hepatic insulin clearance compared to white SA women (7) and black SA men (8). However, the majority of these studies have been undertaken in premenopausal women $(6,7,10)$, with limited data in middle-aged men and women (8).

Notably, men typically have greater central fat mass (particularly visceral adipose tissue 21 (VAT)) and less peripheral subcutaneous adipose tissue (SAT) than women, which is associated with a higher risk for T2D $(8,11,12)$. However, the sex differences in the association between whole body and regional adiposity, and T2D risk, including insulin sensitivity, secretion and clearance, to our knowledge, has not been studied in African men and women. 
medRxiv preprint doi: https://doi.org/10.1101/2021.10.19.21265228; this version posted October 26, 2021. The copyright holder for this preprint (which was not certified by peer review) is the author/funder, who has granted medRxiv a license to display the preprint in perpetuity.

Accordingly, the aims of this study were to compare insulin sensitivity, clearance and beta-cell

27 function between middle-aged black South African men and women who differ in obesity

prevalence, and to explore sex-specific associations with total and regional adiposity.

\section{Methods}

31 This cross-sectional study includes the analysis of the follow-up data that was part of a longitudinal study designed to investigate the determinants of T2D risk in middle-aged black

SA men and women. Data collection for the baseline study, as part of the AWI-Gen (Africa

Wits-INDEPTH partnerships for Genomic Research) study (13), took place between 2011 and 2015 in black SA men $(n=1027)$ and women $(n=1008)$ residing in Soweto, South Africa (14).

Follow-up data, analysed for this study, was collected between January 2017 and August 2018 on a sample of 502 men and 527 women randomly selected from the original sample.

Participants living with HIV were excluded from this data analysis to avoid the confounding effects of the virus and antiretroviral therapy on the outcomes. Complete data was available for 804 participants (388 men and 416 women) and complete oral glucose tolerance (OGTT) data was available on 734 of these participants (Supplementary files: Figure 1).

The study was conducted in accordance with the tenets of the Helsinki declaration and was approved by the Human Research Ethics Committee (HREC) of the University of the Witwatersrand (M160604 and M160975). Prior to inclusion in the study all procedures and possible risks were explained and all participants signed a consent form. Data collection took place at the South African Medical Research Council/University of the Witwatersrand 
medRxiv preprint doi: https://doi.org/10.1101/2021.10.19.21265228; this version posted October 26, 2021. The copyright holder for this preprint (which was not certified by peer review) is the author/funder, who has granted medRxiv a license to display the preprint in perpetuity.

51 Socio-demographic and medical questionnaire

52 Interviewer administered questionnaires were completed and captured onto REDCap (15).

53 Data collected included age, marital status (married/unmarried), current employment

54 (employed/not employed), highest educational level completed (no formal

schooling/elementary school, secondary school level, tertiary education), alcohol intake and tobacco consumption (Yes/No), and self-reported diabetes and/or diabetes medication taken. Menopausal stage was classified according to last menstrual period (16).

\section{Anthropometry}

Weight was measured to the nearest $0.1 \mathrm{~kg}$ using a TANITA digital scale (model: TBF-410,

TANITA Corporation, US). Height was measured to the nearest $0.1 \mathrm{~cm}$ using a wall-mounted stadiometer (Holtain, UK). Waist circumference (WC) and hip circumference (HC) were measured to the nearest $0.1 \mathrm{~cm}$ with a non-stretchable tape. For the $\mathrm{WC}$, the tape was placed horizontally between the iliac crest in the mid-axillary plane and the lowest rib margin. For the $\mathrm{HC}$, the tape was placed around the level of the greatest protrusion of the buttocks. Waistto-hip ratio (WHR) and BMI were calculated, and participants categorised according to the World Health Organisation (WHO) criteria (17).

\section{Body composition and body fat distribution measurements}

Dual-energy X-ray absorptiometry (DXA) was used to measure whole body composition, including sub-total (total body minus head to account for any artefacts that may influence the DXA reading) fat mass (FM, kg and \% body mass) and fat-free soft tissue mass (FFSTM), and regional FM including trunk, arm and leg FM (QDR 4500A, Hologic Inc., Bedford, USA, APEX software version 4.0.2). Fat mass index (FMI, sub-total fat mass kg/height ${ }^{2}$ ) and FFSTM index (FFSTM/height ${ }^{2}$ ) were calculated. Regional fat distribution was expressed relative to 
medRxiv preprint doi: https://doi.org/10.1101/2021.10.19.21265228; this version posted October 26, 2021. The copyright holder for this preprint (which was not certified by peer review) is the author/funder, who has granted medRxiv a license to display the preprint in perpetuity. sub-total FM $(\% \mathrm{FM})$, with trunk fat $(\% \mathrm{FM})$ representing central fat distribution and arm and leg fat $(\% \mathrm{FM})$ representing upper- and lower-body peripheral fat distribution, respectively. Abdominal VAT and SAT areas were estimated from DXA (18).

\section{Blood sampling and analysis}

81 Blood samples $(10 \mathrm{ml})$ were drawn after an overnight fast for the determination of glycated haemoglobin (HbA1c), plasma glucose, serum insulin, C-peptide and follicle stimulating hormone (FSH) concentrations. Participants then completed a standard $75 \mathrm{~g}$ oral glucose tolerance test (OGTT) over 2-hours during which blood samples $(5 \mathrm{ml})$ were drawn at $30 \mathrm{~min}$ intervals for the determination of glucose, insulin and C-peptide concentrations. Participants with known diabetes and/or those with fasting blood glucose $\geq 11.1 \mathrm{mmol} / \mathrm{l}(\mathrm{n}=76)$ (ACCU$\mathrm{CHEK}^{\circledR}$, MedNet GmbH, Munster, Germany) did not complete the OGTT.

Plasma glucose concentrations were measured on the Randox RX Daytona Chemistry Analyser (Randox Laboratories Ltd., London, UK). HbA1c concentrations were measured using the D$10^{\mathrm{TM}}$ Haemoglobin Analyser (Bio-Rad Laboratories, Inc. USA). Serum insulin and C-peptide concentrations were measured on the Immulite ${ }^{\circledR} 1000$ Immunoassay System (Siemens Chemiluminescent Healthcare GmbH, Henkestr, Germany). FSH was measured on serum using the ARCHITECT Chemiluminescent Microparticle Immunoassay assay (Abbott Laboratories, Abbott Ireland).

Based on the fasting plasma glucose (FPG) and 2-h OGTT glucose results, participants were classified according to the WHO criteria (19). Participants with impaired fasting glucose and

99 impaired glucose tolerance were combined and described as having impaired glucose 100 metabolism (IGM). 
medRxiv preprint doi: https://doi.org/10.1101/2021.10.19.21265228; this version posted October 26, 2021. The copyright holder for this preprint (which was not certified by peer review) is the author/funder, who has granted medRxiv a license to display the preprint in perpetuity. It is made available under a CC-BY-NC 4.0 International license.

\section{Calculations from the OGTT}

103 The homeostasis model assessment (HOMA-IR) was used to estimate fasting insulin resistance

104 (20). The Matsuda Index (21), was used to estimate insulin sensitivity for participants with 105 complete OGTT data $(\mathrm{n}=628)$, alongside the composite score (22) for participants who only 106 had data for 0 and 120 minutes $(n=106)$. These composite measures have been shown to 107 compare well (22), and were significantly correlated in this study $(r=0.874 ; p<0.001)$ to the

108 Matsuda Index. Early phase insulin response to the OGTT was estimated using the 109 insulinogenic index (IGI) (23). Participants without data at 30 minutes or whose insulin 110 response was $<0$ were excluded from the analysis. Insulin secretion was calculated using the

111 C-peptide index, the ratio of the increment in C-peptide relative to glucose in the first 30 112 minutes of OGTT (23). C-peptide is produced in equimolar quantities to endogenous insulin,

113 and unlike insulin, there is negligible hepatic extraction of C-peptide, and hence the C-peptide

114 index and the C-peptide to insulin ratio may serve as proxy measures of insulin secretion and 115 clearance, respectively $(24,25)$. Basal and postprandial insulin clearance were calculated as the 116 ratio of fasting $\mathrm{C}$-peptide to insulin, and the incremental area under the curve (iAUC) of C117 peptide to iAUC insulin, calculated using the trapezoidal method, respectively. The oral 118 disposition index (oDI), which reflects insulin secretion adjusted for the level of insulin 119 sensitivity (26-28), was calculated as the product of the C-peptide index and Matsuda index 120 (23) which demonstrated a hyperbolic relationship and was used as the measure of beta-cell 121 function. These calculations were only performed in participants without known T2D and/or not taking medications for T2D, and who underwent an OGTT.

\section{Statistical analysis}


medRxiv preprint doi: https://doi.org/10.1101/2021.10.19.21265228; this version posted October 26, 2021. The copyright holder for this preprint (which was not certified by peer review) is the author/funder, who has granted medRxiv a license to display the preprint in perpetuity.

125 Data were analysed using Stata $15.1 / \mathrm{IC}$ (StataCorp, College Station, TX, USA). Variables are

126 summarised as percentages for categorical data, mean \pm standard deviation (SD) for normally

127 distributed continuous data, and median $\left(25^{\text {th }}-75^{\text {th }}\right.$ percentile $)$ if not normally distributed.

128 Normality was assessed using the Shapiro-Wilk test and Q-Q probability plots. Sex differences

129 were determined using Students t-test for normally distributed continuous data, Mann-Whitney

$130 \mathrm{U}$ and Kruskal-Wallis tests for skewed continuous data, and Chi-squared test for categorical

131 data. Sex differences in glucose and insulin measures are presented before and after adjusting

132 for FMI using one-way analysis of covariance (ANCOVA). Z-scores were derived for the total

133 and regional adiposity measures for the combined sample, as well as sex-stratified using

134 Fisher's Yates transformation (29). By using Z-scores we were able to compare the risk magnitude per 1 SD change in total and regional adiposity measurements. Multinomial logistic regression was used to explore the relationship between total and regional adiposity measures, and IGM and T2D, using NGT as the reference, and including age, sex, smoking, alcohol

138 intake, education, and FMI (for regional measures), as covariates. All participants with known $139(\mathrm{n}=65)$ and newly diagnosed $(\mathrm{n}=42)$ diabetes were included in the multinomial analyses. We 140 explored sex*adiposity z-score interactions and only found a significant interaction for FMI.

141 Accordingly, the data (excluding FMI) were analysed in the combined sample and the relative 142 risk ratio (RRR) and 95\% confidence intervals for IGM and T2D are presented. For the 143 continuous measures of insulin sensitivity (Matsuda index), clearance (fasting C144 peptide/insulin ratio) and beta-cell function (oDI), robust regressions were used to explore 145 associations with adiposity z-scores, including age, smoking, alcohol intake, education and 146 FMI (for regional adiposity measures) as covariates. Participants with known diabetes and/or 147 taking medication for diabetes and those without OGTT data were excluded from the robust 148 regression analyses. Due to significant sex interactions in most models, the analyses were 
medRxiv preprint doi: https://doi.org/10.1101/2021.10.19.21265228; this version posted October 26, 2021. The copyright holder for this preprint (which was not certified by peer review) is the author/funder, who has granted medRxiv a license to display the preprint in perpetuity. completed separately for men and women using sex-specific total and regional adiposity $\mathrm{z}$ scores. A p-value of $<0.05$ was considered significant.

\section{Results}

\section{Socio-demographic and body composition characteristics}

154 A total of 804 participants $(48.3 \%$ men $)$ with a mean age of $54.6 \pm 6.0$ years were included

155 (Table 1). Men were younger than women and significantly more men were married than 156 women. Current employment status was not different between the sexes, however more men 157 than women (18.1 vs. $12.5 \%)$ had completed tertiary education.

Mean BMI was higher in women than men $(\mathrm{p}<0.001)$, and accordingly a larger proportion of

160 the women presented with obesity (70.2\% vs. $26.6 \%)$ (Table 1$)$. While waist circumference

161 was similar, men had higher WHR due to the higher hip circumference of the women. While

162 FFSTM was higher in men, FM (kg and \%) and FMI were higher in women. When expressed

163 relative to FM, women had significantly greater leg FM, while men had more central FM

164 (trunk), but arm FM did not differ. Within the central depot, men had less VAT and SAT (both $\mathrm{p}<0.001$ ), but a higher VAT/SAT ratio.

167 Differences in glucose and insulin measures between men and women

168 Although fasting glucose and iAUC for glucose were not different between the sexes, HbA1C and $2 \mathrm{~h}$ glucose were higher in women than men (Table 1). Fasting insulin and C-peptide, and iAUC for insulin, were also higher in women than men. Accordingly, HOMA-IR was higher

171 and insulin sensitivity (Matsuda index) was lower in women compared to men, accompanied

172 by a higher insulin response (IGI) characterised by higher insulin secretion (C-peptide index) 
medRxiv preprint doi: https://doi.org/10.1101/2021.10.19.21265228; this version posted October 26, 2021. The copyright holder for this preprint (which was not certified by peer review) is the author/funder, who has granted medRxiv a license to display the preprint in perpetuity.

173 and lower insulin clearance (basal and postprandial). However, the oDI, a measure of beta-cell

174 function, did not differ by sex.

175

176 When adjusting for differences in FMI (Table 2), there were no longer sex differences in

177 HbA1C, 2-hour glucose, insulin response, or basal and postprandial insulin clearance, while

178 insulin secretion remained higher in women. In contrast, fasting insulin and C-peptide, as well

179 as HOMA-IR were higher, and insulin sensitivity and beta-cell function were lower in men

180 compared to women.

181

182 The prevalences of NGT, IGM and T2DM were not significantly different between men and 183 women.

184

Associations between total and regional adiposity and risk for IGM and type 2 diabetes

There was a significant sex*FMI z-score interaction $(p<0.001)$, such that the RRR for IGM and

187 T2D were greater for men than women (Figure 1A). Associations between regional adiposity

188 z-scores and risk for IGM and T2D did not differ by sex, and the RRR for the combined sample

189 are presented in Table 3. Trunk fat and VAT z-scores were associated with a higher risk for

190 both IGM and T2D, with every 1 SD increase in trunk fat and VAT being associated with a 4.8

191 fold and 2.6 fold increased risk for T2D, respectively. In contrast, higher leg fat z-score was

192 associated with a 58\% and 79\% lower risk for IGM and T2D, respectively, while a 1 SD higher

193 arm fat z-score was associated with a 2.2-fold greater risk for T2D only. SAT z-score was not

194 associated with IGM or T2D.

195

196 Sex-specific associations between total and regional adiposity z-scores and insulin

197 measures 
medRxiv preprint doi: https://doi.org/10.1101/2021.10.19.21265228; this version posted October 26, 2021. The copyright holder for this preprint (which was not certified by peer review) is the author/funder, who has granted medRxiv a license to display the preprint in perpetuity.

198 There were significant sex*FMI Z-Score interactions for insulin sensitivity, clearance and beta-

199 cell function, with associations consistently being stronger in men than women (Figure 1B-

200 1D). There were also significant sex*regional adiposity interactions for most measures of

201 insulin sensitivity and response and therefore the results are presented separately for men and

202 women (Table 4). Lower insulin sensitivity was associated with higher central fat mass (trunk

203 fat and VAT), and lower leg fat in both men and women, but the associations with central fat

204 mass were stronger in men than women $(\mathrm{p}<0.001$ for all interactions $)$. In contrast, arm fat mass

205 was associated with lower insulin sensitivity in women only ( $<<0.001$ for interaction). Beta-

206 cell function (oDI) was negatively associated with VAT in both men and women. In contrast

207 beta-cell function was positively associated with peripheral fat mass in women only ( $\mathrm{p}=0.040$

208 for interaction). Basal insulin clearance was negatively associated with trunk fat mass in both men and women, with a stronger association in men ( $\mathrm{p}=0.017$ for interaction). In contrast, basal

210 insulin clearance was negatively associated with VAT and arm fat, and positively associated

211 with leg fat in women only, but the strength of the association did not differ significantly

212 between sexes. The associations for postprandial insulin clearance were similar to those for

213 basal insulin clearance (data not shown). As the women were at different phases of the

214 menopausal transition with $17.6 \%$ being premenopausal, $14.7 \%$ perimenopausal and $67.7 \%$

215 being postmenopausal, we wanted to ascertain whether the associations presented above

216 differed by menopausal phase. The associations between total and regional adiposity and

217 insulin sensitivity, secretion and beta-cell function did not differ between menopausal groups.

218 In contrast, the associations between FMI, trunk, leg and arm z-scores and basal insulin

219 clearance differed by menopausal phase, being stronger in the pre- than peri- and 220 postmenopausal women (data not shown).

\section{Discussion}


medRxiv preprint doi: https://doi.org/10.1101/2021.10.19.21265228; this version posted October 26, 2021. The copyright holder for this preprint (which was not certified by peer review) is the author/funder, who has granted medRxiv a license to display the preprint in perpetuity.

223 The main and novel findings of this study were that in a sample of black men and women with

224 a mean age of 54.6 years, after adjustments for differences in body fat, insulin sensitivity,

225 secretion and beta-cell function were lower in black SA men compared to women, while insulin

226 clearance did not differ by sex. In line with this, the strength of the association between total

227 adiposity and T2D risk was greater in men compared to women. Although black SA women

228 have a higher prevalence of obesity (70.2 vs. 26.6\%) and greater whole-body fatness (43.6 vs.

$22926.3 \%$ ) than men, they present with a more 'favourable' body fat distribution, characterised by

230 less central fat mass and greater peripheral fat mass. This phenotype has been associated with

231 lower diabetes risk. This together with the greater impact of body fatness on diabetes risk could

232 explain the similar prevalence of diabetes in men and women (11.1 vs. 15.4\%) despite the

233 lower adiposity in men in this study.

234

235 These findings also suggest that with increasing adiposity, black SA men will be at greater risk

236 for T2D than their female counterparts. We found that the association between total adiposity

237 and risk for T2D was higher in men than women (Figure 1A). Further we showed that with

238 increasing FMI the decline in insulin sensitivity was greater in men compared to women,

239 similar to earlier studies from SA $(8,30)$, which was also associated with a more pronounced

240 decrease in beta-cell function in men compared to women.

242 The finding of similar T2D prevalence (1) despite marked differences in the prevalence of

243 obesity (3) between sexes are consistent and representative of South Africa and the SSA region.

244 In order to understand the sexual dimorphism in this relationship, it is obviously essential to

245 account for sex differences in body fatness as well as disentangle the sex-specific associations

246 between regional adiposity and T2D risk. After adjusting for differences in body fatness, men

247 had lower insulin sensitivity, insulin secretion and beta-cell function compared to women, 
medRxiv preprint doi: https://doi.org/10.1101/2021.10.19.21265228; this version posted October 26, 2021. The copyright holder for this preprint (which was not certified by peer review) is the author/funder, who has granted medRxiv a license to display the preprint in perpetuity. placing the men at higher risk for T2D. Indeed, a lower beta-cell function, estimated using the

249 oDI, has been shown to predict the development of T2D over a 10 year period in a Japanese

250 American cohort (26).

252 Black African women have been shown to present with hyperinsulinaemia compared to their

253 European counterparts, often beyond that required to maintain normoglycaemia $(8,31)$.

254 Hyperinsulinemia in black African women has previously been attributed to alterations in both insulin secretion and clearance, depending on age, and/or level of glycemia $(10,32)$. Studies in African American women have shown that decreased hepatic insulin clearance is the main contributor to hyperinsulinemia (33). In contrast, we show that the higher IGI in women compared to men, was associated with higher insulin secretion without differences in insulin clearance. Due to limited longitudinal studies, it is not known whether the higher IGI in women is protective or may actually cause insulin resistance (9).

262 It is well recognised globally and in South Africa that men have greater central body fat and

263 less lower body peripheral fat compared to women $(8,30)$. Similarly, we showed that men had greater trunk fat mass, a higher VAT/SAT ratio, and less leg and similar arm fat mass than women. This adiposity phenotype is associated with greater diabetes risk $(8,30,32,34)$. Indeed, we showed that a 1SD increase in trunk z-score was associated with a more than two-fold

267 greater risk for IGM and nearly five times greater risk for T2D, and was also associated with

268 lower insulin sensitivity and lower basal insulin clearance. In contrast, peripheral fat is typically associated with reduced risk for diabetes $(30,34)$. We showed that a 1 SD increase in

270 leg z-score was associated with a 58\% lower risk for IGM and a 79\% lower risk for T2D, as

271 well as higher insulin sensitivity in both sexes. Notably, the strength of the inverse association

272 between central fat distribution and insulin sensitivity was greater in men compared to women. 
medRxiv preprint doi: https://doi.org/10.1101/2021.10.19.21265228; this version posted October 26, 2021. The copyright holder for this preprint (which was not certified by peer review) is the author/funder, who has granted medRxiv a license to display the preprint in perpetuity.

273 Several studies in different populations have shown VAT to be more strongly associated with

274 insulin resistance, and therefore a greater risk for T2DM, in men than women (30,35-37). A

275 further a novel finding of the study was that the positive relationship between beta-cell function

276 and leg FM was weaker in men compared to women, suggesting lower 'protective' effect of

277 leg FM on beta-cell function in men compared to women. Accordingly, despite a lower 278 prevalence of overweight and obesity in men compared to women in our study, this

279 'unfavourable' regional fat distribution and the sex-specific relationships with insulin

280 sensitivity and beta-cell function places them at greater risk for future T2D.

282 This is the first study, to our knowledge, in black SA men and women with detailed measures 283 of insulin sensitivity, secretion and clearance, and beta-cell function, based on estimates from an OGTT. We were also able to use DXA, which provides an accurate assessment of body composition and regional adiposity. A limitation is the cross-sectional nature of the study which does not allow us to infer causality. Although the sex differences in obesity and total

287 adiposity may be seen as a limitation, it reflects the status of obesity within South Africa and the sub-Saharan African region (3), and adjustments for total body fatness and the calculation of z-scores were used in the analyses to determine whether these sex differences in adiposity were influencing the insulin- and glucose-related variables. There were no effects of the menopausal transition per se on the association between adiposity and insulin sensitivity,

292 secretion and beta-cell function and therefore the sex differences reported cannot be explained

293 by menopausal status. Furthermore, the conclusions for this study are valid only for HIV negative individuals.

296 In summary, for the same level of body fatness, black South African men are less insulin 297 sensitive and had lower insulin secretion and beta-cell function than women, with the strength 
medRxiv preprint doi: https://doi.org/10.1101/2021.10.19.21265228; this version posted October 26, 2021. The copyright holder for this preprint (which was not certified by peer review) is the author/funder, who has granted medRxiv a license to display the preprint in perpetuity. 298 of the association between adiposity and T2D risk being greater in men compared to women.

299 This suggests that with increasing adiposity, particularly an increase in central adiposity, black

300 SA men face an increased risk for T2D in comparison with their female counterparts.

301 Longitudinal studies are required to confirm the results of this study.

Funding: The study was jointly funded by the South African Medical Research Council (MRC) from South African National Department of Health, MRC UK (via the Newton Fund) and GSK Africa Non-Communicable Disease Open Lab (via a supporting Grant project Number: ES/N013891/1) and South African National Research Foundation (Grant no: UID:98561).

Conflict of Interest: No potential conflicts of interest relevant to this article were reported

Authors' contributions: CNK, JHG and LKM designed the study and CNK analysed the data, drafted and revised the manuscript under the supervision of JHG and LKM. All authors reviewed/edited, read and approved all the drafts and the final version of the manuscript. The authors retained the control of the final content of the publication.

Acknowledgements: We are grateful to the participants as well as the following DPHRU staff for their input during data collection and entry: Melikhanya Soboyisi, Tshifhiwa Ratshikombo, Vukosi Mkansi, Sphume Thango, Mosadiapula Nakedi, Thabile Sibiya, Bonisiwe Mlambo, Caroline Makura, Dr Mamosilo Lichaba, Karabo Pearl Nkhahle and team, and Prof Michèle Ramsay for AWI-Gen study development and oversight. 
medRxiv preprint doi: https://doi.org/10.1101/2021.10.19.21265228; this version posted October 26, 2021. The copyright holder for this preprint (which was not certified by peer review) is the author/funder, who has granted medRxiv a license to display the preprint in perpetuity. It is made available under a CC-BY-NC 4.0 International license.

\section{References}

1. IDF. Diabetes Atlas, 9th Edition 2019. 2019.

2. Kengne AP, Bentham J, Zhou B, Peer N, Matsha TE, Bixby H, et al. Trends in obesity and diabetes across Africa from 1980 to 2014: An analysis of pooled population-based studies. Int J Epidemiol. 2017;46(5):1421-32.

3. Ramsay M, Crowther NJ, Agongo G, Ali SA, Boua RP, Gómez-olivé FX, et al. Regional and sex-specific variation in BMI distribution in four sub-Saharan African countries : The H3Africa AWI-Gen study Regional and sex-specific variation in BMI distribution in four sub-Saharan. Glob Health Action. 2018;11(2).

4. Peer N, Steyn K, Lombard C, Lambert E V., Vythilingum B, Levitt NS. Rising Diabetes Prevalence among Urban-Dwelling Black South Africans. PLoS One. 2012;7(9).

5. NDoH, Stats SA S\& I. South Africa Demographic and Health Survey 2016. 2019.

6. Goedecke JH, Dave JA, Faulenbach M V, Utzschneider KM, Lambert E V, West S, et al. Insulin response in relation to insulin sensitivity: An appropriate $\beta$-cell response in black South African women. Diabetes Care. 2009;32(5):860-5.

7. Goedecke JH, Keswell D, Weinreich C, Fan J, Victor H. Ethnic differences in hepatic and systemic insulin sensitivity and their associated determinants in obese black and white South African women. 2015;58(11):2647-52.

8. Goedecke JH, George C, Veras K, Peer N, Lombard C, Victor H, et al. Sex differences in insulin sensitivity and insulin response with increasing age in black South African men and women. Diabetes Res Clin Pract. 2016;122:207-14.

9. Goedecke JH, Olsson T. Pathogenesis of type 2 diabetes risk in black Africans: a South African perspective. J Intern Med. 2020;1-11.

10. Goedecke JH, Mtintsilana A, Dlamini SN, Pascal Kengne A. Type 2 diabetes mellitus in African women. Diabetes Res Clin Pract. 2017;123:87-96.

11. Bredella MA. Sex differences in body composition. Adv Exp Med Biol. 2017;1043:927.

12. Schorr M, Dichtel LE, Gerweck A V., Valera RD, Torriani M, Miller KK, et al. Sex differences in body composition and association with cardiometabolic risk. Biol Sex Differ. 2018;9(1):1-10.

13. Ramsay M, Crowther N, Tambo E, Agongo G, Baloyi V, Dikotope S, et al. H3Africa AWI-Gen Collaborative Centre: A resource to study the interplay between genomic and environmental risk factors for cardiometabolic diseases in four sub-Saharan African countries. Glob Heal Epidemiol Genomics. 2016;

14. Ali SA, Soo C, Agongo G, Alberts M, Amenga-Etego L, Boua RP, et al. Genomic and environmental risk factors for cardiometabolic diseases in Africa: methods used for Phase 1 of the AWI-Gen population cross-sectional study. Glob Health Action. 2018;11(sup2).

15. Harris PA, Taylor R, Thielke R, Payne J, Gonzalez N, Conde JG. Research electronic data capture (REDCap)-A metadata-driven methodology and workflow process for providing translational research informatics support. J Biomed Inform. 2009;

16. Jaff NG, Snyman T, Norris SA, Crowther NJ. Staging reproductive aging using stages of reproductive aging workshop +10 in black urban african women in the study of women entering and in endocrine transition. Menopause. 2014;21(11):1225-33.

17. WHO. Expert Committee on Physical Status: The use and interpretation of anthropometric physical status. World Health Organization technical report series. Geneva; 1995.

18. Micklesfield LK, Goedecke JH, Punyanitya M, Wilson KE, Kelly TL. Dual-Energy X- 
medRxiv preprint doi: https://doi.org/10.1101/2021.10.19.21265228; this version posted October 26, 2021. The copyright holder for this preprint (which was not certified by peer review) is the author/funder, who has granted medRxiv a license to display the preprint in perpetuity.

Ray Performs as Well as Clinical Computed Tomography for the Measurement of Visceral Fat. Obesity. 2012;20(5):1109-14.

19. WHO. Classification of diabetes mellitus. Vol. 21, WHO. Geneva; 2019.

20. Matthews DR, Hosker JP, Rudenski AS, Naylor BA, Treacher DF, Turner RC. Homeostasis model assessment: insulin resistance and $\beta$-cell function from fasting plasma glucose and insulin concentrations in man. Diabetologia. 1985;28(7):412-9.

21. Matsuda M, DeFronzo RA. Insulin sensitivity indices obtained from oral glucose tolerance testing: Comparison with the euglycemic insulin clamp. Diabetes Care. 1999;22(9):1462-70.

22. DeFronzo RA, Matsuda M. Reduced time points to calculate the composite index. Vol. 33, Diabetes Care. 2010. p. 2010.

23. Tura A, Kautzky-Willer A, Pacini G. Insulinogenic indices from insulin and Cpeptide: Comparison of beta-cell function from OGTT and IVGTT. Diabetes Res Clin Pract. 2006;72(3):298-301.

24. Polonsky KS, Rubenstein AH. C-peptide as a measure of the secretion and hepatic extraction of insulin. Pitfalls and limitations. Vol. 33, Diabetes. 1984. p. 486-94.

25. Leighton E, Sainsbury CA, Jones GC. A Practical Review of C-Peptide Testing in Diabetes. Vol. 8, Diabetes Therapy. Springer Healthcare; 2017. p. 475-87.

26. Utzschneider KM, Prigeon RL, Faulenbach M V., Tong J, Carr DB, Boyko EJ, et al. Oral Disposition index predicts the development of future diabetes above and beyond fasting and 2-h glucose levels. Diabetes Care. 2009;32(2):335-41.

27. Kahn SE, Prigeon RL, McCulloch DK, Boyko EJ, Bergman RN, Schwartz MW, et al. Quantification of the relationship between insulin sensitivity and $\beta$ - cell function in human subjects: Evidence for a hyperbolic function. Diabetes. 1993;42(11):1663-72.

28. Mather KJ, Chen M, Hannon TS. Linearization of the Disposition Index equation allows evaluation of secretion-sensitivity coupling slopes. J Diabetes Complications. 2020;34(7):107589.

29. Armitage P BG. Statistical Methods in Medical Research, 2002. Blackwell Science Ltd: Oxford, UK. Blackwell Science Ltd: Oxford, UK; 2002.

30. Davidson FE, Matsha TE, Erasmus RT, Kengne AP, Goedecke JH. Associations between body fat distribution and cardiometabolic risk factors in mixed-ancestry South African women and men. Cardiovasc J Afr. 2019;30(6):321-30.

31. Lee CC, Haffner SM, Wagenknecht LE, Lorenzo C, Norris JM, Bergman RN, Stefanovski D, Anderson AM, Rotter JI, Goodarzi MO HA. Insulin Clearance and the Incidence of Type 2 Diabetes in Hispanics and African Americans. Diabetes Care. 2013;36:901-7.

32. Mtintsilana A, Micklesfield LK, Chorell E, Olsson T, Goedecke JH. Fat redistribution and accumulation of visceral adipose tissue predicts type 2 diabetes risk in middleaged black South African women: a 13-year longitudinal study. Nutr Diabetes. 2019;9(1).

33. Kodama K, Tojjar D, Yamada S, Toda K, Patel CJ BA. Ethnic Differences in the Relationship Between Insulin Sensitivity and Insulin Response. A systematic review and meta-analysis. Diabetes Care. 2013;36(6):1789-96.

34. Keswell D, Tootla M, Goedecke JH. Associations between body fat distribution, insulin resistance and dyslipidaemia in black and white South African women. Cardiovasc J Afr. 2016;27(3):177-83.

35. Kautzky-willer A, Harreiter J, Pacini G. Sex and Gender Differences in Risk, Pathophysiology and Complications of Type 2 Diabetes Mellitus. 2016;37(June):278316.

36. Geer EB, Shen W. Gender differences in insulin resistance, body composition, and 
medRxiv preprint doi: https://doi.org/10.1101/2021.10.19.21265228; this version posted October 26, 2021. The copyright holder for this preprint (which was not certified by peer review) is the author/funder, who has granted medRxiv a license to display the preprint in perpetuity. energy balance. G is made available under a CC-BY-NC 4.0 International license.

37. De Mutsert R, Gast K, Widya R, De Koning E, Jazet I, Lamb H, et al. Associations of Abdominal Subcutaneous and Visceral Fat with Insulin Resistance and Secretion Differ between Men and Women: The Netherlands Epidemiology of Obesity Study. Metab Syndr Relat Disord. 2018;16(1):54-63. 
medRxiv preprint doi: https://doi.org/10.1101/2021.10.19.21265228; this version posted October 26, 2021. The copyright holder for this preprint (which was not certified by peer review) is the author/funder, who has granted medRxiv a license to display the preprint in perpetuity.

Table 1: Socio-demographic, body composition, glucose and insulin measures in black South African men and women $(\mathbf{n}=\mathbf{8 0 4})$

\begin{tabular}{|c|c|c|c|}
\hline Variable & Men & Women & p-value \\
\hline $\mathrm{n}(\%)$ & $388(48.3 \%)$ & $416(51.7 \%)$ & - \\
\hline Age (years) & $54.2 \pm 6.2$ & $55.0 \pm 5.8$ & 0.047 \\
\hline \multicolumn{4}{|l|}{ Socio-demographic characteristics, row: n (\%) } \\
\hline Married, $\mathrm{n}(\%)$ & $219(56.7)$ & $186(44.9)$ & 0.001 \\
\hline Currently employed (n, \%) & $232(47.3)$ & $258(52.6)$ & 0.519 \\
\hline Currently smokes, $\mathrm{n}(\%)$ & $179(46.1)$ & $30(7.2)$ & $<0.001$ \\
\hline \multicolumn{4}{|l|}{ Alcohol intake, n (\%) } \\
\hline Never & $107(27.6)$ & $304(73.1)$ & \\
\hline Sometimes (monthly or less and 2-4 times a month) & $163(42.0)$ & $93(22.4)$ & \\
\hline Often (2-3 times and 4 or more times a week) & $118(30.4)$ & $19(4.6)$ & $<0.001$ \\
\hline \multicolumn{4}{|l|}{ Educational attainment, $\mathrm{n}(\%)$} \\
\hline No formal schooling/elementary school level & $43(11.1)$ & $38(9.2)$ & \multirow{3}{*}{0.042} \\
\hline Secondary school level & $274(70.8)$ & $325(78.3)$ & \\
\hline Tertiary education & $70(18.1)$ & $52(12.5)$ & \\
\hline \multicolumn{4}{|l|}{ Body composition } \\
\hline Height $(\mathrm{cm})$ & $171 \pm 6$ & $158 \pm 6$ & $<0.001$ \\
\hline Weight $(\mathrm{kg})$ & $77.4 \pm 18.4$ & $85.4 \pm 18.0$ & $<0.001$ \\
\hline $\operatorname{BMI}\left(\mathrm{kg} / \mathrm{m}^{2}\right)$ & $26.4 \pm 6.0$ & $34.0 \pm 7.0$ & $<0.001$ \\
\hline Waist circumference $(\mathrm{cm})$ & $96.1 \pm 15.4$ & $97.4 \pm 13.1$ & 0.191 \\
\hline Hip circumference $(\mathrm{cm})$ & $100.6 \pm 11.1$ & $116.6 \pm 13.6$ & $<0.001$ \\
\hline WHR & $0.95 \pm 0.06$ & $0.84 \pm 0.10$ & $<0.001$ \\
\hline \multicolumn{4}{|l|}{ BMI categories, n (\%) } \\
\hline Underweight $\left(<18.5 \mathrm{~kg} / \mathrm{m}^{2}\right)$ & $26(6.7)$ & $2(0.5)$ & \multirow{4}{*}{$<0.001$} \\
\hline Normal weight $\left(18.50-24.99 \mathrm{~kg} / \mathrm{m}^{2}\right)$ & $145(37.4)$ & $31(7.5)$ & \\
\hline Overweight $\left(25-29.99 \mathrm{~kg} / \mathrm{m}^{2}\right)$ & $115(29.6)$ & $90(21.6)$ & \\
\hline Obese $\left(\geq 30.0 \mathrm{~kg} / \mathrm{m}^{2}\right)$ & $102(26.3)$ & $293(70.4)$ & \\
\hline \multicolumn{4}{|l|}{ DXA $(n=763)$} \\
\hline Fat-free soft tissue mass $(\mathrm{kg})$ & $49.4 \pm 9.1$ & $41.7 \pm 7.0$ & $<0.001$ \\
\hline Fat-free soft tissue mass index $\left(\mathrm{kg} / \mathrm{m}^{2}\right)$ & $16.8 \pm 2.8$ & $16.6 \pm 2.6$ & 0.270 \\
\hline Body fat mass (kg) & $20.9 \pm 8.9$ & $37.7 \pm 10.3$ & $<0.001$ \\
\hline Body fat $(\%)$ & $26.3 \pm 6.2$ & $44.0 \pm 4.8$ & $<0.001$ \\
\hline Fat mass index $\left(\mathrm{kg} / \mathrm{m}^{2}\right)$ & $7.1 \pm 3.0$ & $15.1 \pm 4.1$ & $<0.001$ \\
\hline Trunk $(\%$ FM) & $46.9 \pm 5.3$ & $43.5 \pm 5.7$ & $<0.001$ \\
\hline $\operatorname{Leg}(\% \mathrm{FM})$ & $40.8 \pm 5.0$ & $43.9 \pm 6.2$ & $<0.001$ \\
\hline $\operatorname{Arm}(\% \mathrm{FM})$ & $12.4 \pm 1.3$ & $12.6 \pm 1.8$ & 0.055 \\
\hline $\operatorname{VAT}\left(\mathrm{cm}^{2}\right)$ & $91.9 \pm 47.4$ & $109.6 \pm 44.7$ & $<0.001$ \\
\hline SAT $\left(\mathrm{cm}^{2}\right)$ & $215.8 \pm 129.5$ & $474.6 \pm 144.3$ & $<0.001$ \\
\hline VAT/SAT & $0.50 \pm 0.19$ & $0.24 \pm 0.09$ & $<0.001$ \\
\hline \multicolumn{4}{|l|}{ Glucose and insulin measures $(n=804)$} \\
\hline HbA1c $(\%)$ & $5.8 \pm 1.1$ & $6.3 \pm 1.4$ & $<0.001$ \\
\hline Fasting glucose $(\mathrm{mmol} / \mathrm{L})$ & $5.3 \pm 1.5$ & $5.5 \pm 2.0$ & 0.057 \\
\hline $2 \mathrm{~h}$ glucose $(\mathrm{mmol} / \mathrm{L})(\mathrm{n})(\mathrm{n}=735)$ & $6.1 \pm 2.6$ & $6.6 \pm 2.7$ & 0.009 \\
\hline iAUC for glucose $(\mathrm{mmol} / \mathrm{L})(\mathrm{n}=735)$ & $177(72-297)$ & $157(79-262)$ & 0.368 \\
\hline Fasting insulin $(\mathrm{mIU} / \mathrm{ml})$ & $5.9(2.3-11.9)$ & $9.4(5.2-15.2)$ & $<0.001$ \\
\hline iAUC for insulin $(\mathrm{mIU} / \mathrm{ml})(\mathrm{n}=735)$ & $4132(2526-7304)$ & $4692(3080-7216)$ & 0.021 \\
\hline
\end{tabular}


medRxiv preprint doi: https://doi.org/10.1101/2021.10.19.21265228; this version posted October 26, 2021. The copyright holder for this preprint (which was not certified by peer review) is the author/funder, who has granted medRxiv a license to display the preprint in perpetuity.

\begin{tabular}{|c|c|c|c|}
\hline Fasting C-peptide (ng/ml) & $1.84 \pm 1.07$ & $2.09 \pm 1.17$ & 0.002 \\
\hline iAUC for C-peptide $(\mathrm{ng} / \mathrm{ml})(\mathrm{n}=735)$ & $641(447-925)$ & $638(465-875)$ & 0.915 \\
\hline HOMA-IR & $1.37(0.51-2.81)$ & $2.11(1.13-3.69)$ & $<0.001$ \\
\hline Matsuda index $\left(\mathrm{mgl}^{2} / \mathrm{mU} \min \right)(\mathrm{n}=734)$ & $7.1(3.6-13.2)$ & $5.0(3.1-8.4)$ & $<0.001$ \\
\hline Insulinogenic Index $(\mathrm{mIU} / \mathrm{mmol})(\mathrm{n}=624)$ & $16.9(8.3-33.0)$ & $23.4(12.7-43.4)$ & 0.001 \\
\hline C-peptide Index (ng/mmol) $(\mathrm{n}=612)$ & $2.25(1.27-3.79)$ & $2.73(1.56-4.57)$ & 0.002 \\
\hline oDI (mIU/mmol) $(\mathrm{n}=644)$ & $13.74(7.22-26.09)$ & $13.40(5.98-28.08)$ & 0.917 \\
\hline Basal insulin clearance (ng/mIU) & $0.28(0.20-0.39)$ & $0.20(0.15-0.27)$ & $<0.001$ \\
\hline Postprandial insulin clearance $(\mathrm{ng} / \mathrm{mIU})(\mathrm{n}=698)$ & $0.18(0.14-0.25)$ & $0.14(0.12-0.17)$ & $<0.001$ \\
\hline \multicolumn{4}{|l|}{ Glucose tolerance status ${ }^{1}$} \\
\hline NGT: $($ FPG <6.1 / 2-h PG <7.8mmol/L) & $263(67.8)$ & $261(62.7)$ & \multirow{3}{*}{0.163} \\
\hline IGM: (FPG: 6.1-6.9 / IGT 2hPG: 7.8-11.0) & $82(21.1)$ & $91(21.9)$ & \\
\hline T2DM: (FPG $\geq 7 / 2-h$ PG $\geq 11.1 /$ diabetes medication) & $43(11.1)$ & $64(15.4)$ & \\
\hline
\end{tabular}

Values expressed as mean $\pm \mathrm{SD}$, median $\left(25^{\text {th }}-75^{\text {th }}\right.$ percentile $)$ or $\mathrm{n}$ (percentage). BMI: body mass index, WHR: waist-hip ratio, DXA: dual x-ray absorptiometry, VAT: visceral adipose tissue, SAT: subcutaneous adipose tissue; HbA1c: glycated haemoglobin, iAUC: integrated area under the curve, HOMA-IR: Homeostatic Model Assessment of Insulin Resistance, NGT: normal glucose tolerance, IGM: impaired glucose metabolism, T2DM: type 2 diabetes mellitus.

Matsuda Index: measure of insulin sensitivity $(21,22)$; Insulinogenic Index: measure of insulin response: $\Delta \mathrm{I}_{30} / \Delta \mathrm{G}_{30}(23)$; C-peptide Index: measure of insulin secretion: $\Delta \mathrm{CP}_{30} / \Delta \mathrm{G}_{30}$ (23); oDI: oral disposition index, measure of beta-cell function, calculated as product of $\mathrm{C}$ peptide index and Matsuda index (26-28); Glycaemic tolerance status ${ }^{1}$ : definition and diagnosis of diabetes and intermediate hyperglycemia: report of a WHO/IDF consultation 
medRxiv preprint doi: https://doi.org/10.1101/2021.10.19.21265228; this version posted October 26, 2021. The copyright holder for this preprint (which was not certified by peer review) is the author/funder, who has granted medRxiv a license to display the preprint in perpetuity.

Table 2: Glucose and insulin measures in black $\mathbf{S A}$ men and women adjusted for FMI

\begin{tabular}{|l|c|c|c|}
\hline Variable, $\mathbf{n}$ & \multicolumn{2}{|c|}{ Adjusted for FMI } \\
\hline Glucose and insulin measures & Men & Women & p-value \\
\hline HbA1c $(\%)(\mathrm{n}=761)$ & $6.0(5.8,6.1)$ & $6.1(6.0-6.3)$ & 0.256 \\
\hline Fasting glucose $(\mathrm{mmol} / \mathrm{L})(\mathrm{n}=763)$ & $5.5(5.3-5.7)$ & $5.2(5.0-5.5)$ & 0.160 \\
\hline 2 h glucose $(\mathrm{mmol} / \mathrm{L})(\mathrm{n}=697)$ & $6.5(6.2-6.9)$ & $6.0(5.7-6.4)$ & 0.116 \\
\hline iAUC for glucose $(\mathrm{mmol} / \mathrm{L})(\mathrm{n}=697)$ & $221(198-244)$ & $163(140-185)$ & 0.003 \\
\hline Fasting insulin $(\mathrm{mIU} / \mathrm{ml})(\mathrm{n}=761)$ & $12.3(11.1-13.5)$ & $7.8(6.6-8.9)$ & $<0.001$ \\
\hline iAUC for insulin $(\mathrm{mIU} / \mathrm{ml})(\mathrm{n}=697)$ & $6387(5842-6932)$ & $4704(4165-5244)$ & 0.001 \\
\hline Fasting C-peptide $(\mathrm{ng} / \mathrm{ml})(\mathrm{n}=761)$ & $2.29(2.16-2.41)$ & $1.59(1.47-1.72)$ & $<0.001$ \\
\hline iAUC for C-peptide $(\mathrm{ng} / \mathrm{ml})(\mathrm{n}=698)$ & $746(631-861)$ & $895(781-1009)$ & 0.123 \\
\hline HOMA-IR $(\mathrm{n}=761)$ & $3.03(2.62-3.44)$ & $2.06(1.66-2.45)$ & 0.005 \\
\hline Matsuda Index $(\mathrm{mgl} / \mathrm{mU} \mathrm{min})(\mathrm{n}=696)$ & $6.3(5.5-7.2)$ & $9.8(8.9-10.6)$ & $<0.001$ \\
\hline Insulinogenic index $(\mathrm{mIU} / \mathrm{mmol})(\mathrm{n}=659)$ & $27.4(16.6-38.3)$ & $43.3(32.3-54.2)$ & 0.089 \\
\hline C-peptide index $(\mathrm{ng} / \mathrm{mmol})(\mathrm{n}=613)$ & $2.75(1.43-4.07)$ & $6.91(5.60-8.22)$ & $<0.001$ \\
\hline oDI $(\mathrm{mIU} / \mathrm{mmol})(\mathrm{n}=613)$ & $14.0(1.7-26.3)$ & $62.3(50.0-74.5)$ & $<0.001$ \\
\hline Basal insulin clearance $(\mathrm{ng} / \mathrm{mIU})(\mathrm{n}=761)$ & $0.27(0.25-0.28)$ & $0.28(0.26-0.29)$ & 0.448 \\
\hline Postprandial insulin clearance $(\mathrm{ng} / \mathrm{mIU})(\mathrm{n}=698)$ & $0.19(0.18-0.21)$ & $0.18(0.17-0.19)$ & 0.403 \\
\hline
\end{tabular}

Data adjusted for fat mass index (FMI) presented as median (95\% Confidence Interval);

HbA1c: glycated haemoglobin,

iAUC: integrated area under the curve,

HOMA-IR: Homeostatic Model Assessment of Insulin Resistance,

Matsuda Index: measure of insulin sensitivity $(24,25)$,

Insulinogenic Index: measure of insulin response: $\Delta \mathrm{I}_{30} / \Delta \mathrm{G}_{30}(26)$,

C-peptide Index: measure of insulin secretion: $\Delta \mathrm{CP}_{30} / \Delta \mathrm{G}_{30}(26)$,

oDI: oral disposition index, measure of beta-cell function, calculated as the product of the C-

peptide index and Matsuda index (29-31) 
Table 3: Associations between regional adiposity z-scores and risk for IGM and type 2 diabetes in men and women combined

\begin{tabular}{|l|c|c|c|c|}
\hline Men and women & RRR & $\mathbf{9 5 \%} \mathbf{C I}$ & p-value & Model R $^{\mathbf{2}}$ \\
\hline Trunk z-score (n=761) & & & & \\
\hline IGM & 2.35 & $1.43-3.87$ & 0.001 & $<0.001$ \\
\hline Type 2 diabetes & 4.76 & $2.68-8.45$ & $<0.001$ & \\
\hline Leg z-score (n=759) & & & & \\
\hline IGM & 0.42 & $0.24-0.71$ & 0.001 & $<0.001$ \\
\hline Type 2 diabetes & 0.21 & $0.11-0.39$ & $<0.001$ & \\
\hline Arm z-score $(\mathbf{n = 7 5 9 )}$ & & & & \\
\hline IGM & 1.35 & $0.83-2.21$ & 0.224 & $<0.001$ \\
\hline Type 2 diabetes & 2.19 & $1.25-3.81$ & 0.006 & \\
\hline VAT z-score (n=753) & & & & \\
\hline IGM & 1.76 & $1.35-2.28$ & $<0.001$ & $<0.001$ \\
\hline Type 2 diabetes & 2.58 & $1.92-3.48$ & $<0.001$ & \\
\hline SAT z-score $(\mathbf{n = 7 5 3 )}$ & & & & \\
\hline IGM & 1.35 & $0.74-2.48$ & 0.331 & $<0.001$ \\
\hline Type 2 diabetes & 1.37 & $0.68-2.75$ & 0.376 & \\
\hline
\end{tabular}

Results of multinomial logistic regression presented as relative risk ratios (RRR) and $95 \%$ confidence interval and represent risk of outcome with $1 \mathrm{SD}$ increase in regional adiposity. Model used normal glucose tolerance (NGT) as the reference group compared to impaired glucose metabolism (IGM) and type 2 diabetes, adjusted for: age, smoking, alcohol intake, education attainment, FMI and sex 
Table 4: Associations between regional adiposity $\mathrm{z}$-scores and insulin sensitivity, basal insulin clearance and Beta-cell function

\begin{tabular}{|c|c|c|c|c|c|c|c|c|c|c|}
\hline & $\mathbf{B}$ & $95 \%$ CI & p-value & Model $\mathbf{R}^{2}$ & Model p-value & $\mathbf{B}$ & $95 \% \mathrm{CI}$ & p-value & Model R $\mathbf{R}^{2}$ & Model p-value \\
\hline & \multicolumn{5}{|c|}{ Men } & \multicolumn{5}{|c|}{ Women } \\
\hline & \multicolumn{5}{|c|}{ Insulin Sensitivity $(n=344)$} & \multicolumn{5}{|c|}{ Insulin Sensitivity $(n=349)$} \\
\hline FMI z-score $^{\#}$ & -3.442 & -4.011 to -2.873 & $<0.001$ & 0.284 & $<0.001$ & -1.225 & -1.631 to -0.819 & $<0.001$ & 0.069 & $<0.001$ \\
\hline Trunk z-score \# & -2.680 & -4.829 to -0.532 & 0.015 & 0.295 & $<0.001$ & -1.748 & -2.545 to -0.950 & $<0.001$ & 0.097 & $<0.001$ \\
\hline Leg z-score & 1.695 & 0.233 to 3.157 & 0.023 & 0.293 & $<0.001$ & 1.218 & 0.454 to 1.982 & 0.002 & 0.086 & $<0.001$ \\
\hline Arm z-score ${ }^{\#}$ & 0.027 & -1.667 to 1.722 & 0.975 & 0.284 & $<0.001$ & -0.893 & -1.716 to -0.070 & 0.033 & 0.080 & $<0.001$ \\
\hline VAT z-score & -1.679 & -2.540 to -0.818 & $<0.001$ & 0.309 & $<0.001$ & -1.174 & -1.657 to -0.691 & $<0.001$ & 0.106 & $<0.001$ \\
\hline \multirow[t]{2}{*}{ SAT z-score ${ }^{\#}$} & -1.043 & -2.961 to 0.876 & 0.286 & 0.286 & $<0.001$ & -0.693 & -1.582 to 0.195 & 0.126 & 0.075 & $<0.001$ \\
\hline & \multicolumn{5}{|c|}{ Beta-cell function $(n=304)$} & \multicolumn{5}{|c|}{ Beta-cell function $(n=306)$} \\
\hline FMI z-score ${ }^{\#}$ & -3.9594 & $-5.3600--2.5589$ & $<0.001$ & 0.065 & $<0.001$ & -2.6420 & -4.0684 to -1.2156 & $<0.001$ & 0.027 & 0.001 \\
\hline Trunk z-score & -4.0597 & -9.2112 to 1.0917 & 0.122 & 0.068 & $<0.001$ & -4.3905 & -7.2286 to -1.5524 & 0.003 & 0.040 & $<0.001$ \\
\hline Leg z-score ${ }^{\#}$ & 3.182 & -0.3294 to 6.6940 & 0.076 & 0.071 & $<0.001$ & 4.3120 & 1.7781 to 6.8460 & 0.001 & 0.044 & $<0.001$ \\
\hline Arm z-score ${ }^{\#}$ & 0.1387 & -3.8845 to 4.1618 & 0.946 & 0.065 & $<0.001$ & -0.5693 & -3.3668 to 2.2282 & 0.689 & 0.028 & 0.001 \\
\hline VAT z-score & -2.6180 & -4.7016 to 0.5344 & 0.014 & 0.074 & $<0.001$ & -3.8567 & -5.5820 to -2.1314 & $<0.001$ & 0.051 & $<0.001$ \\
\hline \multirow[t]{2}{*}{ SAT z-score } & 1.6166 & -2.9625 to 6.1957 & 0.488 & 0.066 & $<0.001$ & -1.8141 & -4.7217 to 1.0936 & 0.220 & 0.029 & 0.001 \\
\hline & \multicolumn{5}{|c|}{ Basal Insulin Clearance $(n=346)$} & \multicolumn{5}{|c|}{ Basal Insulin Clearance $(n=351)$} \\
\hline FMI z-score $^{\#}$ & -0.047 & -0.062 to -0.033 & $<0.001$ & 0.121 & $<0.001$ & -0.027 & -0.035 to -0.018 & $<0.001$ & 0.092 & $<0.001$ \\
\hline Trunk z-score ${ }^{\#}$ & -0.055 & -0.109 to -0.001 & 0.047 & 0.129 & $<0.001$ & -0.026 & -0.044 to -0.009 & 0.002 & 0.108 & $<0.001$ \\
\hline Leg z-score & 0.006 & -0.031 to 0.044 & 0.738 & 0.121 & $<0.001$ & 0.017 & 0.001 to 0.033 & 0.036 & 0.099 & $<0.001$ \\
\hline Arm z-score ${ }^{\#}$ & -0.015 & -0.058 to 0.027 & 0.477 & 0.122 & $<0.001$ & -0.022 & -0.038 to -0.005 & 0.011 & 0.104 & $<0.001$ \\
\hline VAT z-score & 0.001 & -0.022 to 0.023 & 0.945 & 0.121 & $<0.001$ & -0.018 & -0.028 to -0.008 & 0.001 & 0.111 & $<0.001$ \\
\hline SAT z-score ${ }^{\#}$ & -0.033 & -0.082 to 0.015 & 0.175 & 0.125 & $<0.001$ & -0.005 & -0.024 to 0.013 & 0.555 & 0.093 & $<0.001$ \\
\hline
\end{tabular}

Beta coefficients for robust regression models for men and women, adjusted for age, smoking, alcohol intake, education attainment and FMI (except for FMI z-score), VAT: visceral adipose tissue, SAT: subcutaneous adipose tissue,

Insulin sensitivity estimated from the Matsuda Index $(24,25)$ and beta-cell function was estimated using the oral Disposition index calculated as the product of C-peptide and Matsuda Index (26), and basal insulin clearance calculated as the ratio of fasting C-peptide to fasting insulin ${ }^{\#} \mathrm{p}<0.05$ for sex* $\mathrm{z}$-score body fat interaction term 

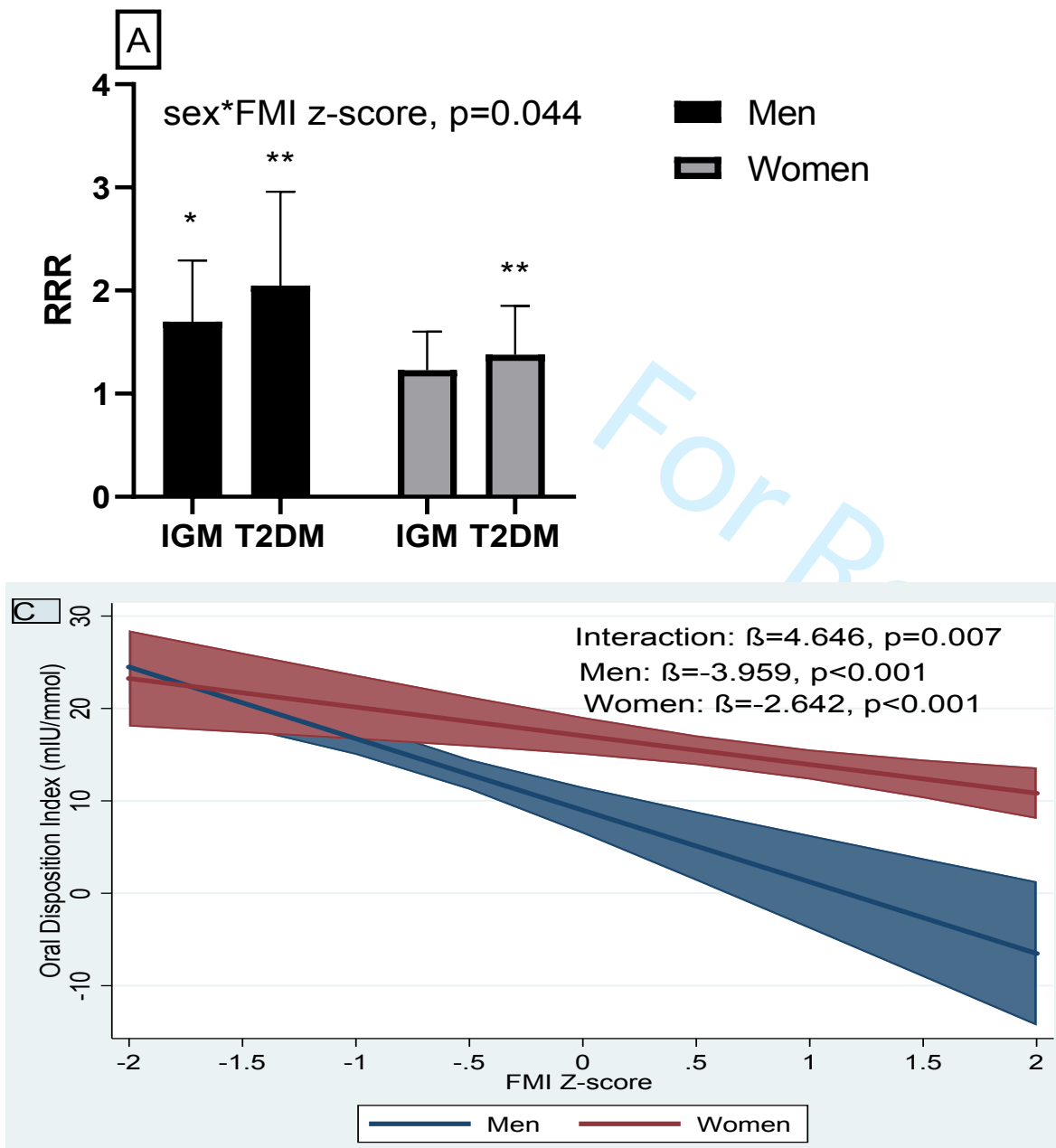
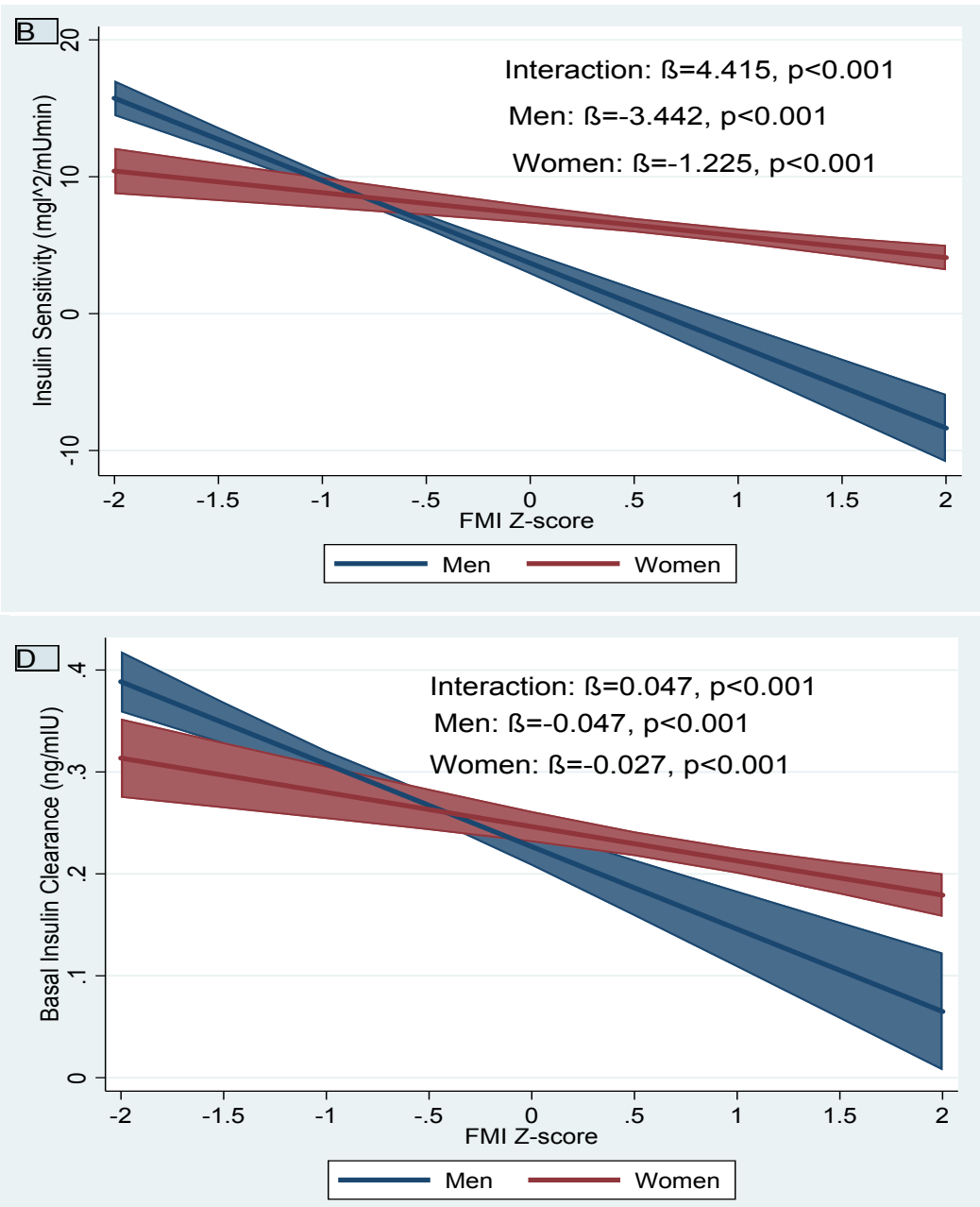

Figure 1: Bar Graph of the relative risk ratio (RRR) of impaired glucose metabolism (IGM) and type 2 diabetes mellitus compared to the normal glucose tolerant (NGT) in men and women, IGM: (RRR (95\%CI): $1.70(1.27-2.29), \mathrm{p}<0.001 \mathrm{vs.} 1.23$ (0.95-1.60), $\mathrm{p}=0.115)$ and T2D: $(2.05(1.42-2.96), \mathrm{p}<0.001$ vs. 1.38 (1.03-1.85), $\mathrm{p}=0.031)$ for men and women, respectively (A); Sex-specific associations between FMI z-scores and insulin sensitivity (Matsuda index) (B), beta-cell function (oral disposition index) (C) and basal insulin clearance (D), modelled as predictive margins of sex with $95 \% \mathrm{CI}$ 